\title{
戸建住宅用小口径鋼管杭の非剛 THE NON-FIXATION PILE CAP 接合杭頭処理方法 PROCESSING METHOD OF SMALL DIAMETER STEEL PIPE PILES FOR SMALL BUILDINGS
}

\section{吾郷秀夫 一 $* 1$ 藤井 衛 — $* 2$ \\ 黒澤太雅 — $* 3$ 荒川範行 $-* 4$}

キーワード :

戸建住宅，小口径鋼管杭，ダクタイル製杭工法，非剛接合，杭頭処理，2001年 芸予地震

Keywords :

Small buildings, Small diameter steel pipe piles, Ductile iron pile method,

Non-fixation, Pile cap processing, 2001 Geiyo Earthquake

\section{Hideo AGOU $* 1$ \\ Mamoru FUJII $-* 2$ \\ Taiga KUROSAWA $-* 3 \quad$ Noriyuki ARAKAWA $-* 4$}

In this study, the performance of non-fixation pile cap processing method using pile cap joint was investigated by using two series of experiments, past construction records and excavations. As the result, it is proved that the performance of pile using this method satisfied the performance requirements for small buildings.

\section{1.はじめに}

小口径鋼管杭による地盤補強は、現在数多くの施工実績がある。 その一方で、鋼管杭の杭頭処理方法は、設計者の指示により、種々 多様な方法で行われているのが現状である。杭頭処理方法は、地震 時に作用する水平力への対処方法と密接な関係を持ち、大別すると 基礎梁と一体化させた剛接合と、回転剛性を低減させる非剛接合が ある。

杭の定義は「水平力に対しても上部構造と一体となって抵抗する もの」であり、従来までは、この定義から杭頭処理方法は、剛接合の ものが主流であった。

しかし兵庫県南部地震において、杭頭を固定した剛接合では、杭 頭接合部での被害が多く報告1)されている。

筆者らは、小規模建築物の場合は、非剛接合の方が良いとの考え を持っている。

なお、論文中の杭頭接合具は、戸建住宅用小口径鋼管杭の非剛接 合杭頭処理方法として、杭頭接合部、フーチング、基礎梁の被害を 防ぐため開発したものであり、平成 13 年芸予地震時には広島県下を 中心に約 3,300 棟の住宅で使用されていたが、被害は報告されてい ない。

以下、杭頭接合具を用いた杭頭処理方法の概要、平成 13 年芸予地 震時の使用状况等を紹介する。

また、当論文で紹介する杭頭接合具及び比較対象となる杭頭処理 方法を、以下の通り定義する。

Type-A : 基礎梁と一体化させた杭頭処理 （図-1（a）参照) Type-B : 杭頭接合具を用いた杭頭処理 (図-1 (b) 参照) Type-C : 杭頭を基礎梁と接合しない杭頭処理 (図-7 (c) 参照)

\section{2. 杭頭接合具の開発プロセス}

\section{1 戸建住宅用小口径鋼管杭の杭頭処理の例}

図一 1 に、戸建住宅用小口径鋼管杭の杭頭処理として用いられて いる基礎梁と一体化させた杭頭処理方法 (剛接合) の例と、杭頭接 合具を用いた杭頭処理方法（非剛接合）の構造を示す。

基礎梁と一体化させた杭頭処理方法は、鋼管杭とフーチング鉄筋 とを結合してフーチング内に埋め込むため、水平力に対してフーチ ング全体で抵抗する構造である。

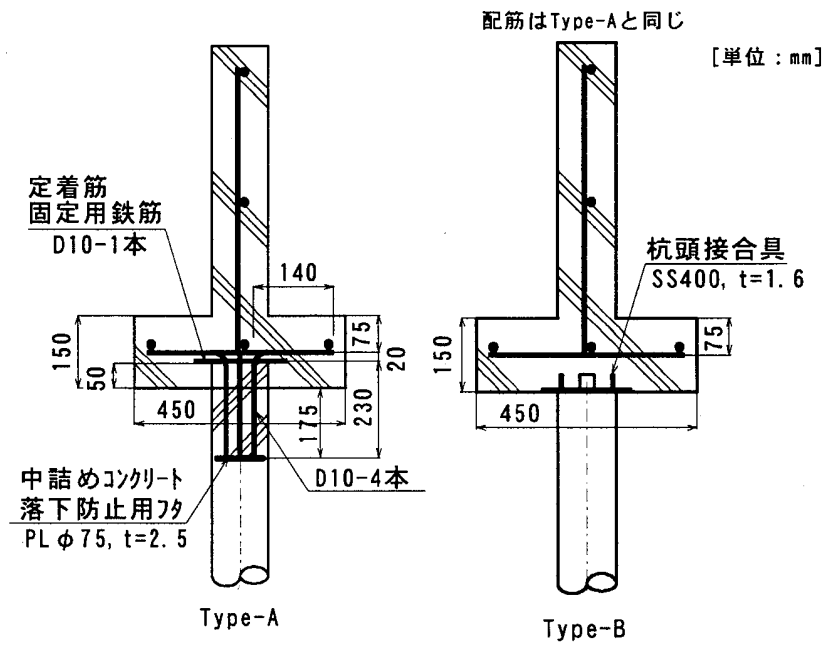
（a）Type-A（基礎梁と一体化）
(b) Type-B（杭頭接合具）

\section{図一１小口径鋼管杭の杭頭処理例及び杭頭接合具の構造}

\footnotetext{
${ }^{* 1}$ Executive Director, Engineering Div., Izumo Construction Co., Ltd.

*2 Prof., Architecture Dept., Faculty of Engineering, Tokai Univ.

*3 Ductile Iron Pile Method Study Group

*4 Section Manager, Ductile Iron Pipe R\&D Dept., Kubota Corp.
} 
杭頭接合具は、鋼管杭とフーチング鉄筋を結合せず、鋼管杭の天 端でフーチングの底面を支える構造である。

なお、台風時の風荷重等に対する安定性を考慮し、高さ $37 \mathrm{~mm} の$ 羽根部がフーチング内に埋め込まれているが、地震時には羽根部が 容易に変形し、フーチングには一定值以上の水平力や曲げモーメン 卜を伝達させないため、杭頭接合部、フーチング、基礎梁の破壊を 防ぐ効果がある。

写真- 1 に杭頭接合具の構造例（杭外径 $118 \mathrm{~mm}$ 用）亡杭頭への 取り付け状况を示す。

当杭頭接合具の材質は、鋼製 (SS400) とステンレス製 (SUS304) がある。杭頭部への取り付けは被せるだけである。
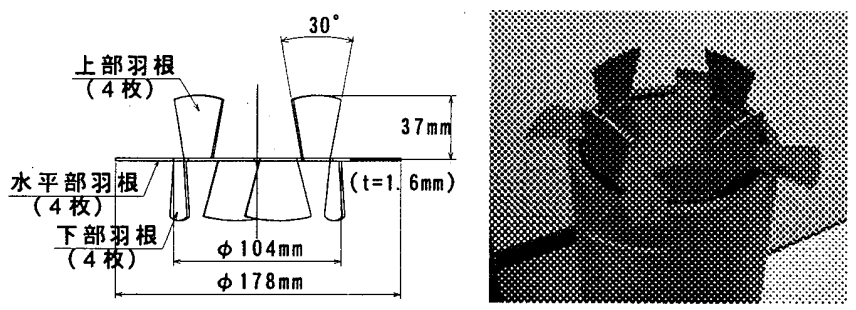

写真一 1 杭頭接合具の構造例と杭頭への取り付け状況

（材質 : 建築構造用ステンレス鋼材、一般構造用圧延銅材）

\section{2 戸建住宅における小口径鋼管杭の要求性能}

ここでは、戸建住宅における小口径鋼管杭に要求される性能を以 下のように設定してみた。

(1) 戸建住宅における杭基礎の主たる目的は、鈶直荷重に対する 不同沈下防止である。

(2) フーチングが小規模な断面であるため、地震力により杭頭部 に発生する曲げモーメントのフーチングへの伝達を極小化す る。

これらの要求性能を満足することが、杭及びフーチングの被災を より小さくすることにつながると考える。

\section{3 戸建住宅における杭頭処理方法の要求性能}

上記の要求性能を実現させるための杭頭処理方法は、以下の通り である。

(1) 杭とフーチングとを完全に固定しない。

(2) 地震力をフーチングに極力伝達させない。

（3）台風時でも建物の安定性を確保する。

杭頭接合具は、前述のように、これら杭頭処理に要求される性能 を满足するものである。

\section{3. 正負交番曲け試験}

杭頭接合具の曲け㓮性を確認し、基礎梁と一体化させた杭頭処理 方法との曲げモーメントの比較を行うため、Type-Aと Type-Bの杭 頭処理方法について、軸力を加えた状態で正負交番曲け試験を実施 した。

\section{1 試験方法}

試験は、図ー 2 に示す一定の軸力を加えた状態で水平方向加力が できる載荷装置を用い、フーチングと同じ仕様（設計基準強度 $21 \mathrm{~N} / \mathrm{mm}^{2}$ ) のコンクリートにセットした杭に、軸力を加えた状態で 曲げ荷重を加えた。

なお、軸力は実用常時支持力及び地震時付加軸力を考慮して $30 \mathrm{kN} 、 50 \mathrm{kN} 、 70 \mathrm{kN}$ の3条件とした。
試験杭は呼ひ徍 $100 \mathrm{~mm}$ ダクタイル製杭(外径 $118 \mathrm{~mm}$ 、管厚 $5.5 \mathrm{~mm}$ 、 旧建設大臣認定材料 建設省 阪 住指発第 412 号:平成 12 年 11 月 8 日取得) を使用した。

杭頭処理は、フーチングを想定したコンクリートに杭頭処理方法 Type-Aと Type-Bをセットした。フーチング寸法は $450 \mathrm{~mm} \times$ $450 \mathrm{~mm}$ とした。

計測項目は、軸力、水平力、変位（杭頭部の両側鈆直方向、加力 点の水平方向、等) を計測した。

加力方法は、一定の軸力（30kN、50kN、70kN の3条件）を加 えた状態で、杭頭部から $1000 \mathrm{~mm}$ 離れた位置から、水平力を変位(回 転角)制御方式で加えて、正負交番曲け試験を行った。

なお、回転角は杭頭部の両側に設けた変位計（図－2に示す変位 計 A-1、A-2） を用いて計測し、0.35/100 $\left(=0.2^{\circ}\right) 、 0.87 / 100(=$ $\left.0.5^{\circ}\right) 、 1.75 / 100\left(=1.0^{\circ}\right) 、 3.49 / 100\left(=2.0^{\circ}\right), 5.24 / 100(=$ $3.0^{\circ}$ )の計 5 サイクルの正負交番曲げとした。

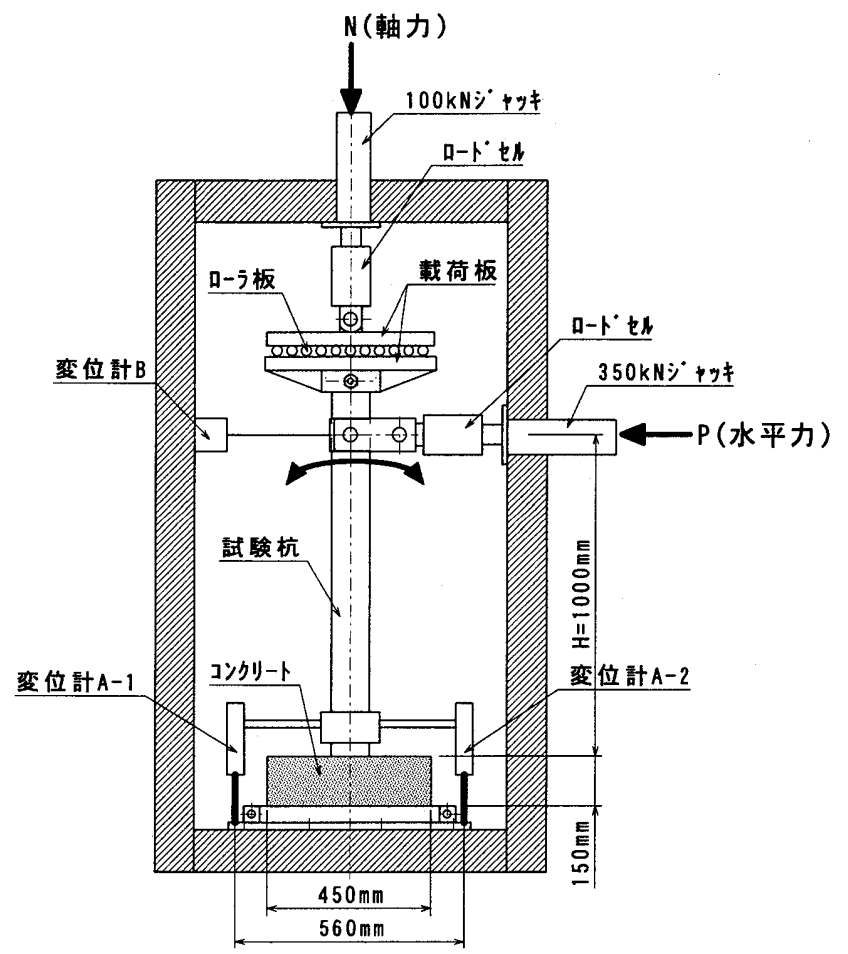

図一2 正負交番曲け試験装置

\section{2 試験結果}

・図ー 3 に杭頭部での曲げモーメントと回転角の関係 (履歴ループ) を示す。

• 図-4に杭頭部での曲げモ一メントと回転角の関係（図ー 3 デー 夕の包絡線) を示す。

・図ー 5 に、図ー4に示す杭頭部での曲げモ一メントを付加軸力で 除した值と回転角の関係を示す。

• 図ー6に各回転角における Type-A と Type-B の杭頭部曲げモ一 メントの比率を示す。

試験の結果、次のことが判つた。

図ー3に示すように杭頭接合具（Type-B）は、基礎梁に一体化 させた杭頭処理方法 (Type-A) に比べ正負交番に伴う履歴減衰は小 さい。また、軸力の増加に伴い、最大曲げモ一メントは増加する。

図ー4、5に示すように杭頭接合具（Type-B）の曲げモーメン 卜は、回転角 $0.2 / 100$ までは直線的に挙動するが、回転角 $0.5 / 100$ 
以降において、曲げモーメント／軸力の值は、0.07〜0.10の範囲で ほぼ一定値となる。

また、基礎梁に一体化させた杭頭処理方法（Type-A）は、回転角 $0.87 / 100$ の時点前後でコンクリートにクラックが生じたが、杭頭接 合具（Type-B）は回転角 5.24/100 でも、杭の天端と接するコン クリートの表面が一部剥離したものの、コンクリート本体にはクラ ックは生じなかった (写真ー 2〜3参照)。

図ー6に示す杭頭部曲げモーメントの比率（Type-B／Type-A） は、軸力にもよるが、0.3〜0.6の值であった。
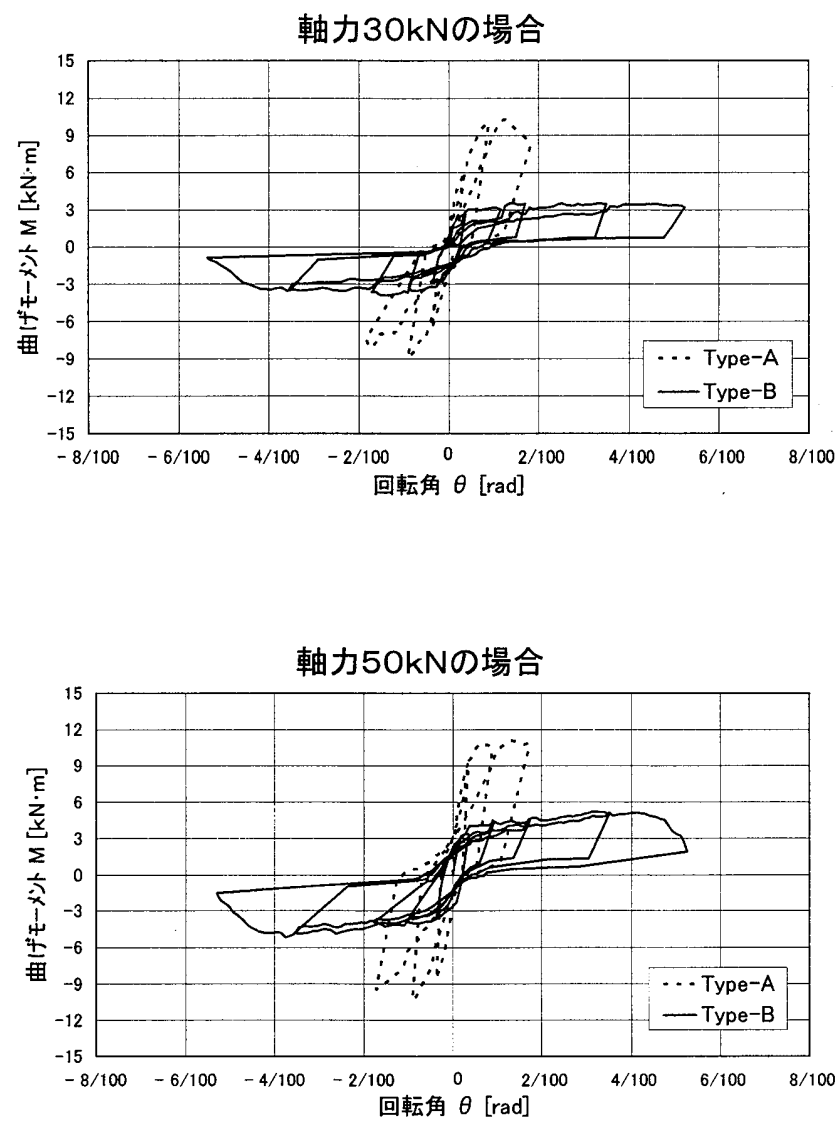

軸力70kNの場合

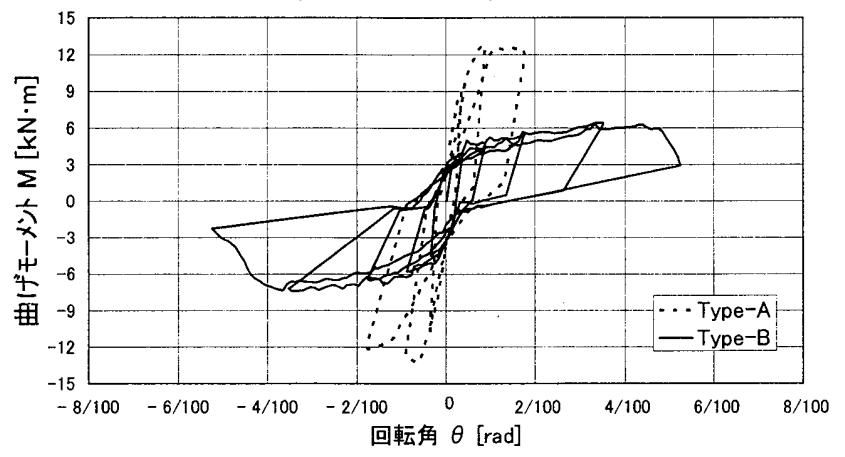

図ー3＼cjkstart杭頭部での曲げモーメントと回転角の関係

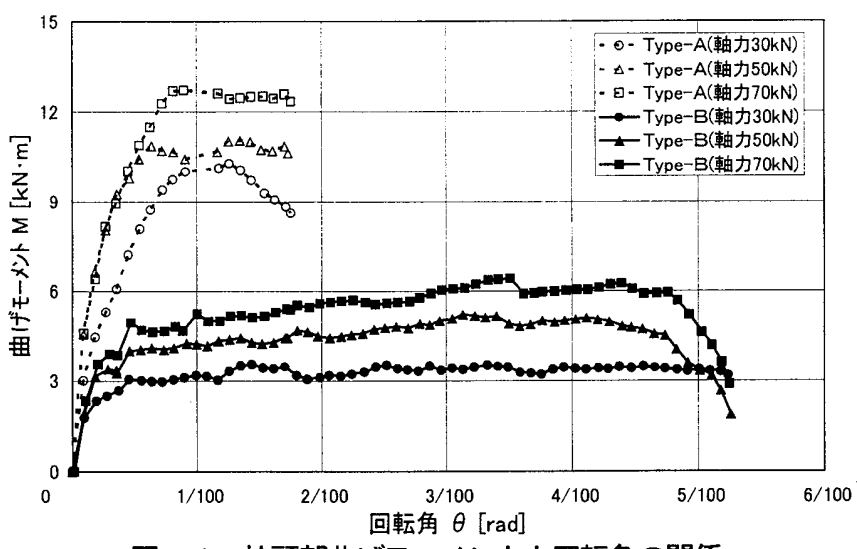

図一4＼cjkstart杭頭部曲げモーメントと回転角の関係

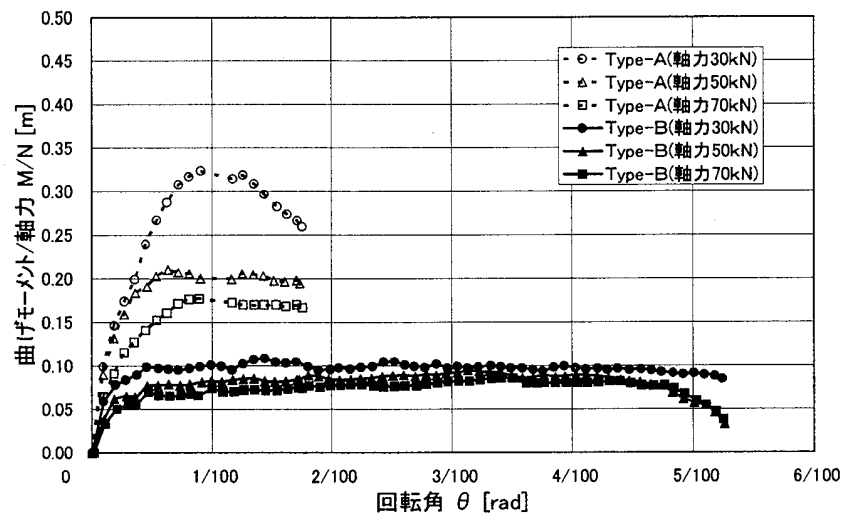

図一5＼cjkstart杭頭部曲げモーメント／軸力と回転角の関係

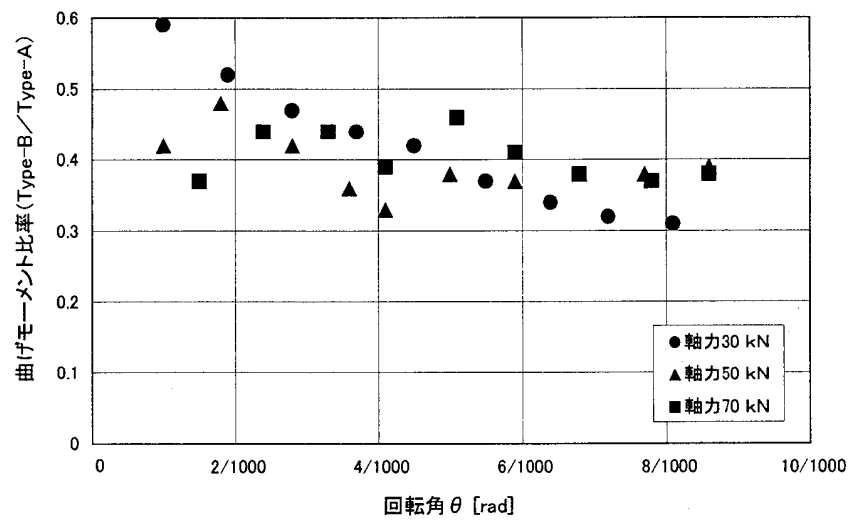

図一6 杭頭部曲げモーメントの比率（Type-Aと Type-B）

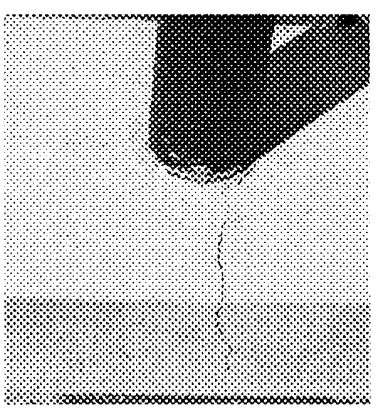

写真- 2 Type-A 試験後の状況

(軸力 : $50 \mathrm{kN}$ 、回転角 $1.75 / 100$ )

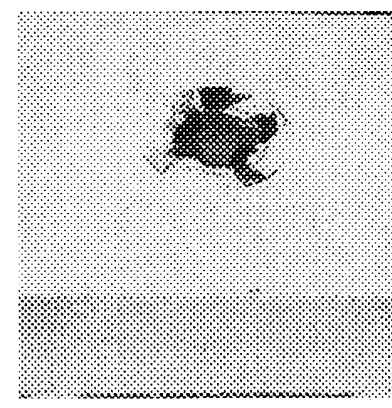

写真-3 Type-B 試験後の状況

(軸力 : 50kN、回転角 5. 24/100) 


\section{3 考察}

以上の試験結果から下記のことが考察される。

(1) Type-Bは、Type-Aに比べて杭頭曲げモ一メントの值は小さ く回転角 $0.5 / 100$ 以降ほぼ一定值となる。これは、回転角 $0.5 / 100$ 以降は、杭頭接合具の下部羽根部が変形することによ るものであり、一定以上の曲げモーメントを伝達しない構造で あるといえる。

(2) Type-Bと Type-Aの杭頭曲げモ一メントの比率は、0.3〜0.6 で ある。杭頭固定度は地盤条件により異なるが、Type-Aの固定度 を $\alpha=0.8$ とした場合、Type-Bの固定度は 0.5 以下と考えられ る。

(3) Type-Aは回転角 $0.87 / 100$ の時点でフーチングコンクリートに ヘアークラックが生じ、以降、構造クラックとなり降伏したが、 Type-Bはコンクリートに何ら損傷は生じなかった。

以上のことから、戸建住宅において、地震時における杭頭接合部 の耐震性は、基礎梁と一体化させた杭頭処理方法 (剛接合) より杭 頭接合具を用いた杭頭処理方法 (非剛接合) の方が優れているとい える。

\section{4. せん断試験}

次に、杭頭を基礎梁と接合しない杭頭処理である図一7に示す杭 頭処理方法とのせん断抵抗力のメカ二ズムを比較し、台風時及び地 震時の安定性について確認するため、軸力を加えた状態で水平方向 加力によるせん断試験を実施した。

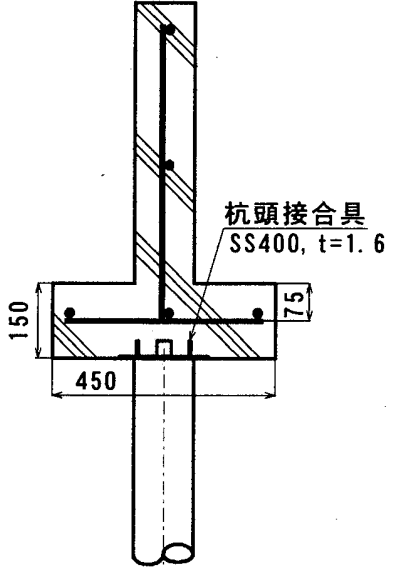

Type-B

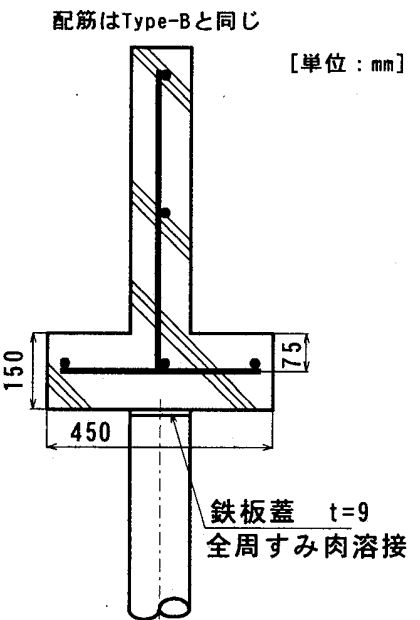

Type-C

（c）Type-C（基礎梁と末接合） (b) Type-B（杭頭接合具）

\section{図一7 非剛接合の杭頭処理方法}

\section{1 せん断試験方法}

試験は、図一8に示す一定の軸力を加えた状態で水平方向加力が できる載荷装置を用い、杭を固定した状態でフーチングに油圧ジャ ッキにて水平方向に加力し、フーチングに取り付けた水平方向変位 計により、杭頭部とフーチングの相対的な水平変位量を測定した。

なお、軸力は実用常時支持力及び地震時付加軸力を考慮して $0 \mathrm{kN}$ 、 $30 \mathrm{kN} 、 70 \mathrm{kN}$ の 3 条件とした。

フーチングコンクリートおよび試験杭は、正負交番曲け試験と同 じ仕様とした。

Type-C の杭頭処理は、厚さ $9 \mathrm{~mm}$ の鉄板蓋を杭頭に全周すみ肉溶 接したもので、フーチングとの接合は載せているだけの状態である。

\section{2 試験結果}

図-9に Type-B、図-10 Type-C の軸力別の水平力と水平変 位の関係を示す。せん断試験の結果、下記のことか判った。

図-9に示すように Type-Bは水平方向力を受けると、まず杭頭 接合具亡杭頭端面の摩擦力で抵抗し、水平方向変位が大きくなると 摩擦力に加え杭頭接合具羽根部の曲け変形あるいはせん断抵抗によ り水平抵抗力を発現する。最大静止摩擦力から計算される杭頭接合 具と杭頭端面の摩擦係数は $\mu=0.3 \sim 0.4$ の值を示す。

なお、Type-Bの羽根部の破壊形態は、軸力 $0 \mathrm{kN}$ 時で曲け破壊、 軸力 $30 \mathrm{kN} 、 70 \mathrm{kN}$ 時でせん断破壊であった (写真 -4 参照)。

一方、図-10に示す Type-Cの水平抵抗力は、鉄板蓋とコンク リートの摩擦力に依存しており、最大静止摩擦力から計算される摩 擦係数は $\mu=0.6 \sim 0.7$ の值を示す。

図一 9〜10の結果をまとめると、水平抵抗力は、軸力 $0 \mathrm{kN}$ 時 にType-Cで $0 \mathrm{kN} 、$ Type-Bで最大 $8 \mathrm{kN}$ で、軸力 $30 \mathrm{kN}$ 時に TypeCで $20 \mathrm{kN}$ 、Type-Bで最大 $24 \mathrm{kN}$ で、軸力 $70 \mathrm{kN}$ 時に Type-Cで $48 \mathrm{kN} 、 T y p e-B て ゙$ 最大 $38 \mathrm{kN}$ であった。

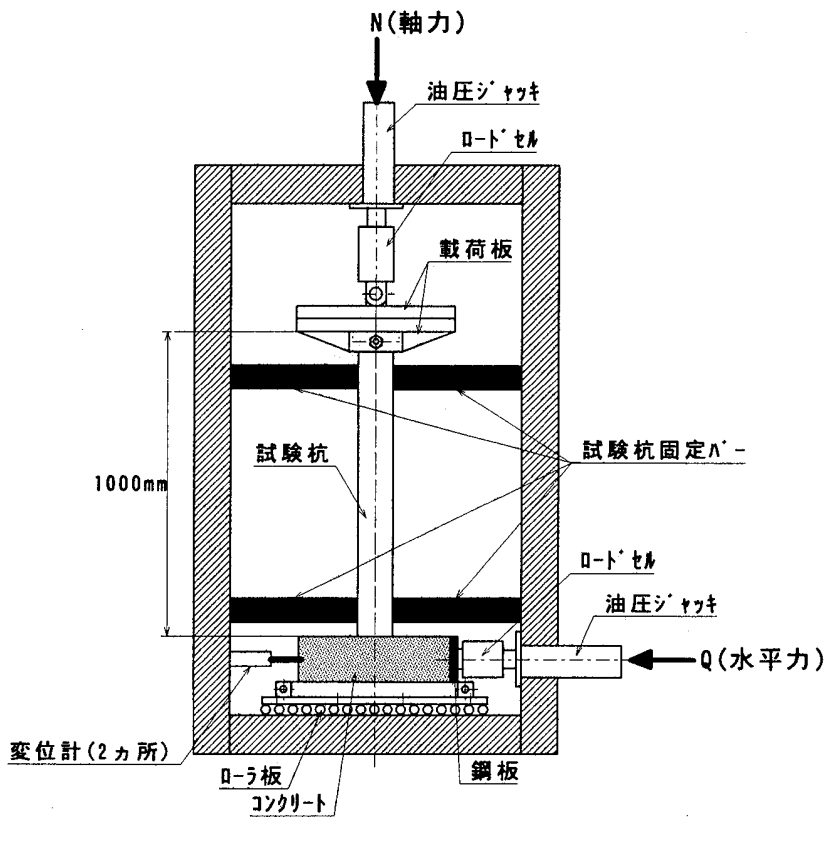

\section{図一8 せん断試験装置図}

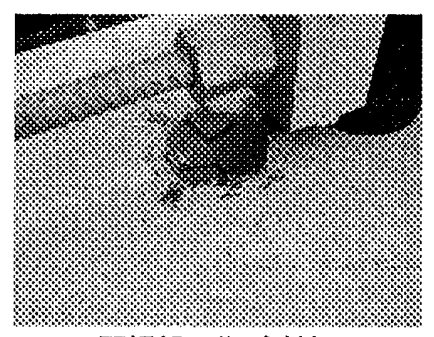

羽根部の曲け破壊

(軸力 : OkN)

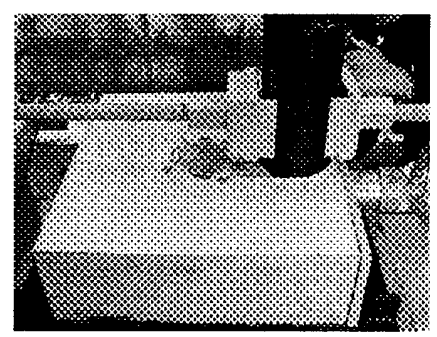

羽根部のせん断破壊

(軸力 : $30 \mathrm{kN} 、 70 \mathrm{kN}$ )
写真一4 杭頭接合具の羽根部の試験後の状況 
軸力別水平力と水平変位の関係 (Type-B)

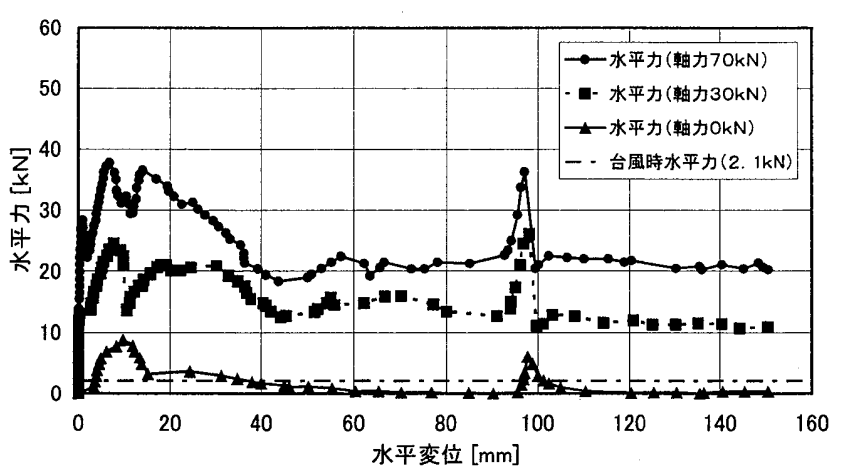

図一9 軸力別水平力と水平変位の関係 (Type-B)

軸力別水平力と水平变位の関係 (Type-C)

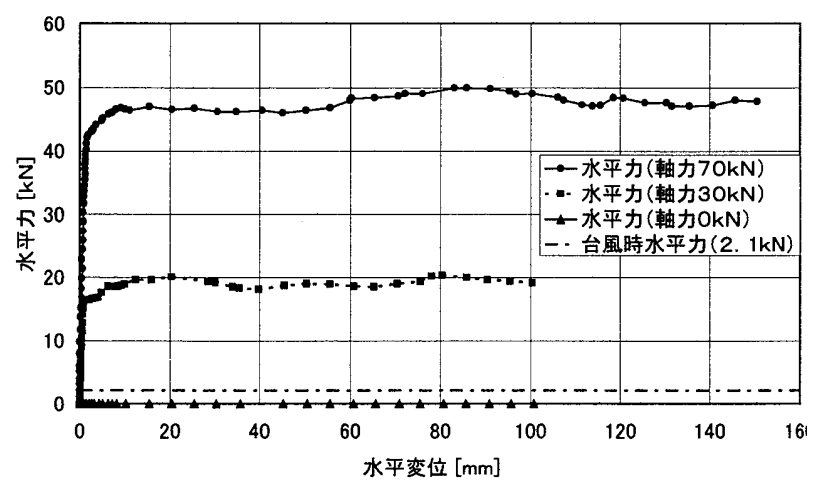

図一10 軸力別水平力と水平変位の関係 (Type-C)

\section{3 考察}

以上の試験結果を踏まえ、図一1 1 に示す木造建物に地震力、 台風時の水平力を作用させた場合の水平抵抗力を計算した。条件 は、地表面粗度保数而、基本風速 $32 \mathrm{~m} / \mathrm{s}$ とし、所要必要抵抗力を 考慮した場合の考察を以下に述べる。

a) 地震時水平抵抗力（R）

建筑基準法で必要とされる、地震時せん断力倸数 $\mathrm{C}=0.2$ 相 当の水平力を考慮し、下式にて求めた。

$$
\begin{array}{ll}
\mathrm{R}=\text { 軸力 } \times \mathrm{C} & \mathrm{R}: \text { 杭 } 1 \text { 本当り必要水平抵抗力 }[\mathrm{kN}] \\
& \mathrm{C}: \text { 地震時せん断力倸数 } \mathrm{C}=0.2
\end{array}
$$

b）台風時水平抵抗力（R）

地表面粗度係数而、基本風速 $32 \mathrm{~m} / \mathrm{s}$ を考慮し、 $\mathrm{R}=2.1 \mathrm{kN}$ とした。

計算結果と試験結果を比較し、次のことが判った。

(1) 軸力 $0 \mathrm{kN}$ 時に、Type-Bは台風時水平力に対しては，安全率 3.8 程度を有するが、Type-Cの抵抗力は期待できない。

(2) 軸力 $30 \mathrm{kN}$ 時に、Type-Bは、台風時水平力に対して安全率 11.4、 地震時水平力に対して安全率 4.0 を有する。Type-Cは，台風時 水平力に対して安全率 9.5、地震時水平力に対して安全率 3.3 を有する。

(3) 軸力 70kN 時に、Type-Bは、台風時水平力に対して安全率 18.1 、 地震時水平力に対して安全率 2.7 を有する。Type-Cは、台風 時水平力に対して安全率 22.8、地震時水平力に対して安全率 3.4 を有する。
これらのことから Type-Bは、地震時の軸力変動に伴う軸力 $0 \mathrm{kN}$ の場合にも水平抵抗力 $8 \mathrm{kN}$ を確保しており、Type-Cに比べ優れた 耐震性を有しているといえる。
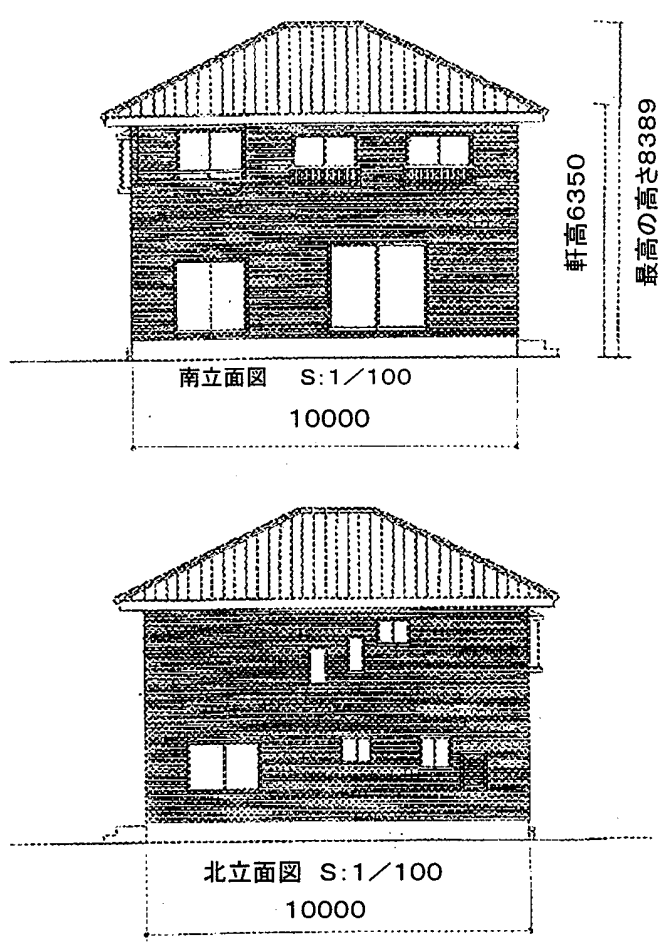

台風時風荷重
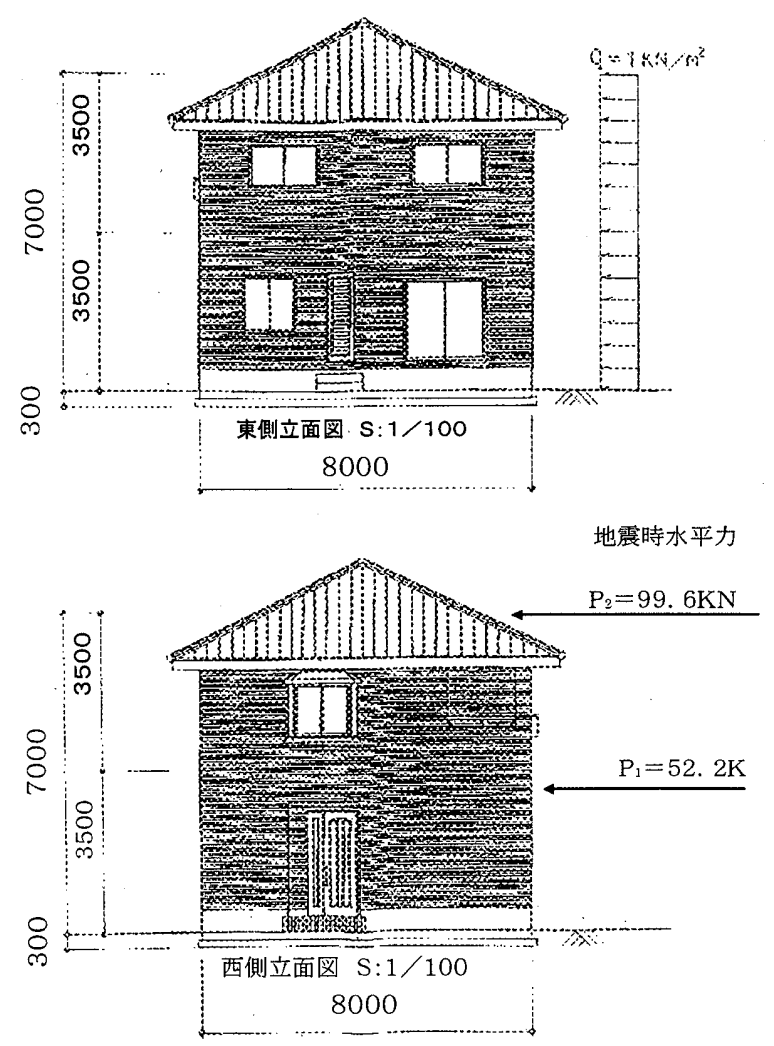

図一11 計算に用いた木造建築物の形状 


\section{2001 年芸予地震時の実績}

\section{1 施工実績}

2001 年芸予地震は、同年 3 月 24 日に安芸灘を震源としたマ グニチュード 6.4 の地震であり、広島県南東部、広島県南西部で最 大震度 6 弱を記録した。各地の震度を図-12 に示す。家屋損壊は 約 520 棟あった。

当論文の杭頭接合具（Type-B）は、2001年芸予地震時には、 広島県下において約 3,300 棟の戸建住宅で使用されていたが、調査 したところ（5.2 杭頭掘り出し調査参照）基礎梁を含む杭頭部での 被害は認められず、また調査地以外の被害報告も受けていない。

図- 13 に、震度 5 強の府中町、震度 5 弱の広島市南区、震度 4 の広島市東区について、杭頭接合具が使用されていた地点を土地区 分図とあわせて示す。

この図からも、杭頭接合具が黄色で示す人工改変地を含む広範囲 で使用されていたことが判る。

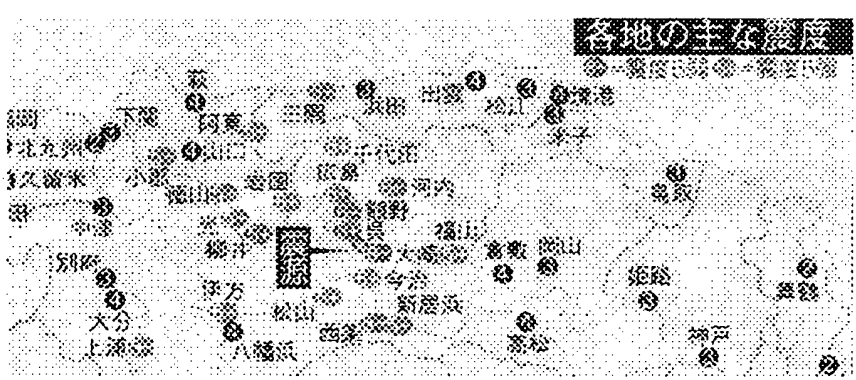

图一-122001年芸予地震の各地の震度

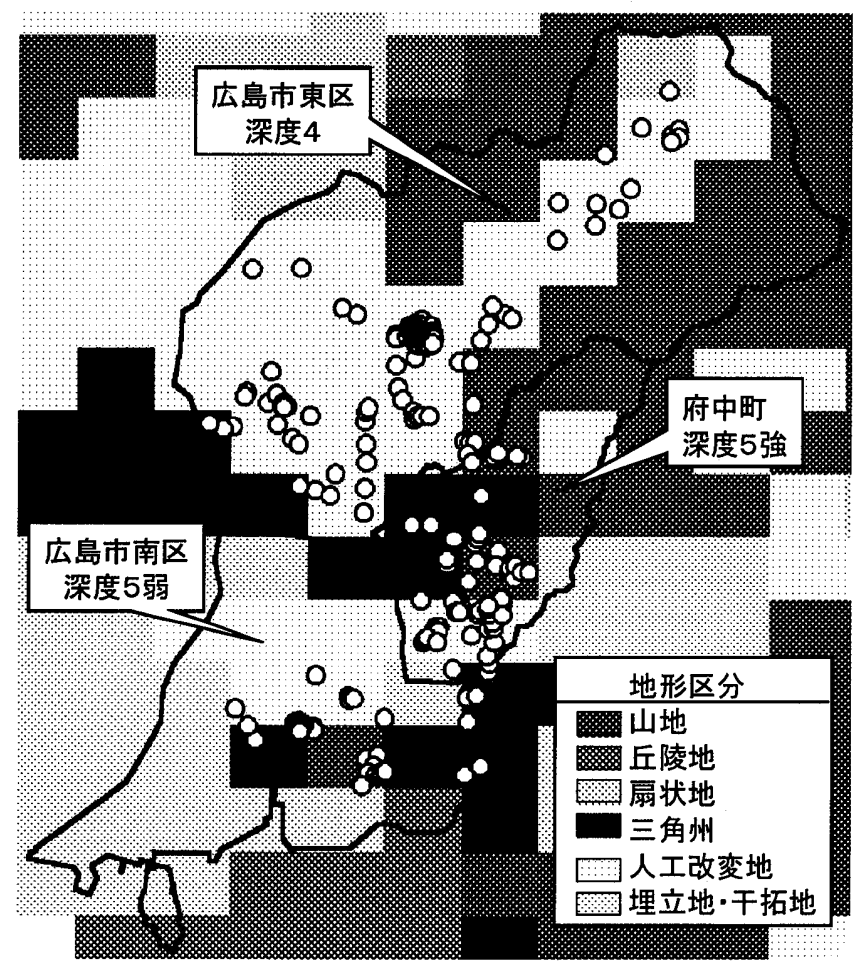

図-13 杭頭接合具の使用地区例

（2０００１年芸予地震）

\section{2 杭頭掘り出し調査}

(1) 杭頭掘り出し調査対象

調查場所 : 広島県吳市

当該場所での最大震度は震度 5 強であった。
建物は木造総 2 階建て、地盤高さ $8 \mathrm{~m}$ の擁壁背面のルーズな埋め 戻し土 (土質 : 真砂土) で、侵食による杭の抜け上がりがみられた。 杭径は $101.6 \mathrm{~mm}$ で杭頭はフーチング下端で切り揃え、杭頭接合具

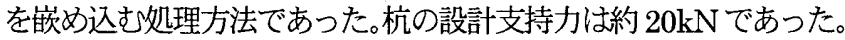

\section{（2）調査結果}

調査結果写真を写真一 5 に示す。調査結果、次のことが判った。 杭と基礎コンクリートは杭頭接合具を挟んで密着しており、杭基 礎として上部構造を支持していた。また、基礎コンクリートにクラ ックは認められず、杭頭部の変形もみられなかった。 杭頭接合具は、鋼管内に嵌め込まれていた羽根部が内側に変形して いたが、破壊はしていなかった。

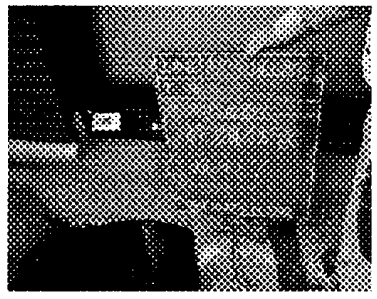

a）基礎コンクリート

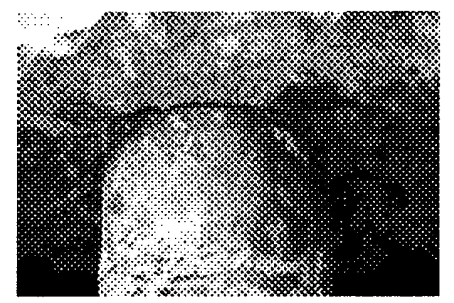

b）杭頭接合部の状況
写真一5 杭頭掘り出し状況

\section{(3) 考察}

以上の調査結果から、下記のことが考察される。

杭頭部、杭頭接合部の基礎コンクリートに被害が生じなかったの は、芸予地震時に発生した杭頭曲げモ一メントに対して杭頭部が非 剛接合であったこと及び、水平力に対して杭頭接合具の羽根部の変 形抵抗による緩衝作用があったためと考えられる。

\section{6. まとめ}

戸建住宅における小口径鋼管杭の杭頭処理方法として、非剛接合 の杭頭接合具について試験結果、施工実績、調查結果を述べた。そ の結果、正負交番試験から一定值以上の曲げモ一メントを伀達しな いこと、せん断試験から杭頭接合具の安定したせん断抵抗力のメ力 ニズムが確認された。また芸予地震時の施工実績や杭頭部掘り出し 調査の結果から、杭頭接合具を用いた非剛接合杭頭処理方法の基礎 及び杭頭部の健全性が確認された。

これらのことから、非剛接な杭頭処理方法は、台風時や地震時で も杭及びフーチングの被災防止に有効であり、戸建住宅における要 求性能を満足するものと判断された。

今後は、ダクタイル製杭や鋼管杭の杭頭処理方法として非剛接合 である杭頭接合具が広く普及されていくものと確信する。

\section{[参考文献}

1）阪神・淡路大震災調查報告 建築編 -4 木造建築物・建築基礎構造 阪神・淡路大震災調查報告編集委員会

2）吾郷秀夫、藤井衛、黒澤太雅、荒川範行 : 戸建住宅用小口径鋼管杭の 非剛接杭頭処理方法 日本建築学会シンポジウム 2003,2

3）日経アーキテクチャア：杭基礎一杭頭を結合しない，2001．3～5

4）例えば，田蔵隆，大槻明，青木孝，真野英之，磯田和彦，岩本利行， 荒川範行, 石原孝浩, 大川雅之 : 建設コストの低減之耐震性能の向上を 目指した新杭頭接合工法の研究開発、第 26 回地震工学研究発表会, 土木 学会, 2001,8

[2003年 4 月16日原稿受理２003年 7 月29日採用決定］ 